\title{
Upaya Meningkatkan Kepercaya Diri Siswa Melalui Konseling Sebaya (Peer Counseling) di SMA Negeri 9 Bandar Lampung
}

\author{
Sri Puji Triani \\ SMA Negeri 9 Bandar Lampung \\ Diterima: Maret 2017. Disetujui: Mei 2017. Dipublikasikan: Juni 2017
}

\begin{abstract}
By looking at the relationship between the more dynamic teens, the BK Teachers can anticipate the provision of $B K$ services by utilizing their peers as a means to be able to provide assistance to their peers. In this PTK researchers improve on efforts to improve student self-confidence. The sample that the researcher took was based on the sociometric assessment data where there were isolated students in the class. The isolated student is assisted by the most favorite students with peer counseling training and it is shown that peer counseling can help improve students' self-confidence.
\end{abstract}

Keywords: Peer; Counseling; Self; Confidence

\begin{abstract}
Abstrak: Dengan melihat hubungan antara remaja yang lebih dinamis, Guru BK dapat mensiasati pemberian layanan BK dengan memanfaatkan teman sebayanya sebagai sarana untuk dapat memberikan bantuan kepada teman sebayanya. Pada PTK ini peneliti meningkatkan pada upaya meningkatkan kepercayaan diri siswa. Sample yang peneliti ambil adalah berdasarkan data assesment sosiometri dimana terdapat siswa yang terisolir di dalam kelas. Siswa yang terisolir tersebut di bantu oleh siswa yang terfavorit dengan diberi pelatihan konseling sebaya dan diperloleh hasil bahwa dengan konseling sebaya dapat membantu meningkatkan percaya diri siswa.
\end{abstract}

Kata Kunci: Konseling; Sebaya; Kepercayaan; Diri

\section{Pendahuluan}

Pada usia remaja tugas pesrkembangan yang harus dipenuhi remaja adalah merencanakan tingkah laku social yang bertanggung jawab. (Sarwono, 2002) Dengan demikian remaja dapat diterima dilingkungannya namun ada kalanya remaja belum dapat melaksanakan tugas perkembangan tersebut dengan tepat, yaitu kurang dapat memaksimalkan kecerdasan interpersonalnaya yang menyebabkan kurang dapat diterima oleh lingkunganya sehingga kurang berhasil dalam kemampuan menetapkan hubungan yang dekat dengan seseorang. Disini peran guru Bimbingan dan Konseling dipandang sangat penting mengingat fungsinya yang sangat strategis, fungsi tersebut adalah mendampingi siswa yang tsengah mesmasuki tahapan remaja dan mselewati masa masa kritiis pubesrtas yg ditandai dengan perubahan fungsi biologis fisik dan psikologis dengan berbagai akibat bawaan yang menyertainya. (Sarlito, 2007)

Dengan melihat hubungan antar remaja yang lebih dinamis guru Bimbingan Konseling dapat mensiasati pemberian layanan Bimbingandan Konseling dengan memanfaatkan teman sebayanya sebagai sarana untuk dapat memberikan bantuan kepada teman sesame sebayanya; dengan pelatihan dan pendampingan sehingga diharapkan tujuan bantuan untuk menyelesaikan masalah dapat terentaskan dengan memanfaatkan hubungan antar remaja/sebaya yang lebih akrab dan terbuka karena ada kecenderungan siswa dalam mengungkapkan segenap informasi dan permasalahannya kepada rekan sebayanya yang disuka akan mengalir dengan deras dibandingkan dengan orang yang lebih dewasa termasuk guru bimbingan dan konselingnya 
sekalipun.

Berkaitan dengan hal tersebut peneliti memperoleh data bahwa terdapat siswa yang terindikasi memiliki kecerdasan interpersonal yang kurang optimal berdasarkan hasil angket sosiometri yang telah diberikan, dari 32 siswa klas XII IPA 1 terdapat 2 orang siswa yang tidak memiliki pemilih untuk kategori teman yang disukai untuk sharing/curhat. Dari data tersebut diperlukan upaya untuk membantu siswa yang kepercayaan dirinya belum maksimal, untuk dapat memaksimalkan potensi pergaulan/sosialnya dengan bantuan sebayanya.

Beberapa uraian di atas membuat peneliti bermaksud mengimplementasikan penggunaan konseling sebaya dalam meningkatkan kepercayaan diri dengan harapan pemberian konseling sebaya dapat menunjang meningkatkan kepercayaan diri siswa disekolah pada siswa klas XII IPA 1 SMAN 9 Bandar Lampung.

Dalam pergaulan sehari hari, kita akan merasa nyaman jika diterima dalam kelompok/komunitasnya, namun seringkali kita kurang mampu bersosialisasi dan bergaul dengan baik, sehingga kurang disukai dalam kelompok, untuk dapat diterima dalam komunitas dan kelompok diperlukan kemampuan menampilkan kepercayaan diri seseorang, kepercayaan diri, merupakan salah satu aspek dari kecerdasan interpersonal, yang sangat mempengaruhi seseorang dalam pergaulan dengan lingkunganya. Kepercayaan diri adalah kondisi mental atau psikologis dari seseorang yang memberi keyakinan kuat pada dirinya untuk berbuat atau melakukan suatu tindakan (Thantaowi, 2005)

Keyakinan akan kemampuan diri atau self efficacy adalah konsep utama yang besar pengaruhnya terhadap perilaku (Winataputra, 2008). Dalam hal ini didefinisikan sebagai penilaian seseorang terhadap kemampuan diri sendiri dalam mengatur dan melaksanakan suatu seri tindakan yang dibutuhkan untuk mendapatkan hasil kerja yang telah ditentukan sebelumnya. Keyakinan pribadi seseorang akan kemampuan dirinya akan berhasil, berdasarkan keyakinan akan kemampuan dirinya dalam mengatasi situasi yang sulit seperti tes, wawancara, mengajar sebuah kelas ataupun dalam mengerjakan sesuatu.

Percaya diri adalah the self yaitu individu sebagaiman diketahui dan dirasakan oleh individu itu sendiri, termasuk didalamnya adalah kepercayaan individu tentang dirinya sendiri yang mencakup siapa, apa dan dimana sebenarnya dirinya berada. Sikap percaya diri merupakan salah satu hal yang sangat mempengaruhi pikiran dan tingkah laku seseorang, percaya diri bukanlah bawaan, namun diperoleh dari pengalaman hidup (Purwanto, 1990).

Membesarkan anak yang percaya pada dirinya sendiri berarti membesarkan seorang pemenang. Percaya diri adalah sebuah sikap diri sikap yang merasa pantas, nyaman dengan diri sendiri dari penilaian orang lain, serta memiliki keyakinan yang kuat (Kevorkian, 2010). Maka sifat tidak percaya diri datang apabila pribadi tersebut tidak merasa pantas, nyaman dan tenang dengan dirinya.

Orang yang tidak percaya diri akan merasa dirinya salah dan memiliki perasaan khawatir (Syaifullah, 2010). Percaya diri merupakan sikap positif yang dimiliki seorang individu yang membiasakan dan memupukkan dirinya untuk mengembangkan penilaian positif baik terhadap diri sendiri maupun terhadap orang lain, lingkungan serta situasi yang dihadapinya untuk meraih apa yang diinginkan (Syaifullah, 2010).

Pribadi seseorang yang memiliki sikap percaya diri diantaranya memiliki ciri-ciri :

a. Percaya dengan kemampuan diri sendiri

b. Mengutamakan usaha sendiri tidak tergantung dengan orang lain.

c. Tidak mudah mengalami rasa putus asaPribadi yang percaya diri akan selalu antusias dalam melakaukan suatu tindakan memiliki tekad, tekun dan pantang menyerah. 
d. Berani menyampiakan pendapat berpendapat merupakan suatu hak yang dimiliki oleh setiap orang, tetapi tidak semuaorang memiliki keberanian untuk menyamapiakn pendapat, rasa takut dan khawatir untuk berbicara merupakan salah satu ciri-ciri sikap tidak percaya dengan kemampuananya

e. Mudah berkomunikasi dan membantu orang lain

f. Tanggungjawab dengan tugas-tugasnya

g. Pribadi yang percaya diri akan selalu memiliki tanggung jawab pada dirinya sendiri yaitu selalu mengerjakan apa yang menjadi tugas dalam menjalankan suatu tindakan, dikerjakan dengan tekun dan rajin.

h. Memiliki cita-cita untuk meraih prestasi

i. Sifat percaya diri hanya dimiliki oleh orang yang bersemangat berjuang dan memiliki kemaun keras, berusaha dan merealisasikan memimpi-mimpinya untuk menjadi kenyataaan.

Pribadi yang percaya diri dari uraian diatas akan dijadaikan sebagai kisi-kisi dalam membuat angket sikap percaya diri. Sosok pribadi yang percaya diri cenderung bisa melawan tantangan hidup yang melintang dalam bentuk apa pun dengan berbuat sesuatu yang bijak dan professional. Rasa percaya diri akan menghasilkan berbagai perasaan atau emosi dalam mengantisipasi suatu tindakan. Setiap tindakan yang dilakukan oleh sesorang akan berbedabeda tergantung usia seseorang, hal tersebut dipengaruhi adanya perkembangan setiap individu. Pembagian fase-fase perkembangan anak mempunyai arti biologis, sebeb perkembangan itu adalah melaksanakan kodrat alam dengan asas pokok, yaitu asas kebutuhan vital ( masa peka ), dan asas kesibukan sendiri. Fase-fase perkembangan itu diantarannya (Desmita, 2009):

a. Periode I, umur 0-7 tahun, yaitu periode penangkapan dan pengenalan dunia luar dengan pancaindra,

b. Periode II, umur 7-12 tahun, yaitu periode abstrak dimana anak mulai menilai perbuatan manusia atas dasar baik-buruk dan mulai timbul insan kamil,

c. Periode III, umur 12-18 tahun, yaitu periode penemuan diri dan kepekaan sosial,

d. Periode IV umur 18 ke atas, yaitu periode pendidikan perguruan tinggi.

Dari individu yang satu dengan yang lain memiliki rasa percaya diri yang berbeda-beda, tergantung dari fase perkembangannya. Usia rata-rata anak Indonesia saat masuk Sekolah Dasar adalah 6 atau 7 tahun, ini menunjukkan bahwa fase perkembangan anak pada periode II, pada usia ini anak akan senang bermain, senang bergerak, senang bekerja dalam kelompok dan senang melakukan sesuatu secara langsung.

Tugas perkembangan anak usia sekolah meliputi (Desmita, 2009):

a. menguasai ketrampilan fisik yang diperlukan dalam permainan dan aktifitas fisik

b. membina hidup sehat

c. belajar bergaul dan bekerja kelompok

d. belajar membaca, menulis, dan berhitung agar mampu berpartisipasi dalam masyarakat,

e. mencapai kemandirian pribadi.

Sikap percaya diri seorang anak tidak hanya dipengaruhi oleh factor perkembangan anak saja, tetapi ada faktor-faktor eksternal yang dapat mempengaruhi adanya sikap percaya diri pada anak diantaranya adalah :

a. Faktor lingkungan keluarga 
Keadaan keluarga merupakan lingkungan hidup yang pertama dan utama dalam kehidupan setiap manusia, lingkungan sangat mempengaruhi pembentukan awal rasa percaya diri pada seseorang. Rasa percaya diri merupakan suatu keyakinan seseorang terhadap segala aspek kelebihan yang ada pada dirinya dan diwujudkan dalam tingkah laku sehari-hari.

b. Pendidikan formal

Sekolah bisa dikatan sebagai lingkungan kedua bagi anak, dimana sekolah merupakan lingkungan yang paling berperan bagi anak setelah lingkungan keluarga di rumah. Sekolah memberikan ruang pada anak untuk mengekpresikan rasa percaya dirinya terhadap temanteman sebayanya.

c. Pendidikan non formal

Salah satu modal utama untuk bisa menjadi seseorang dengan kepribadian yang penuh rasa percaya diri adalah memiliki kelebihan tertentu yang berarti bagi diri sendiri dan orang lain. Rasa percaya diri akan menjadi lebih mantap jika seseorang memiliki suatu kelebihan yang membuat orang lain merasa kagum dan dirinya memiliki prestasi. Kemampuan atau keterampilan dalam bidang tertentu bisa didapatkan melalui pendidikan non formal misalnya : mengikuti kursusbahasa asing, jurnalistik, bermain alat musik, seni vokal, keterampilan memasuki dunia kerja, pendidikan keagamaan dan lain sebagainya. Sebagai penunjang timbulanya rasa percaya diri pada diri individu yang bersangkutan.

Selain sikap percaya diri, kecerdasan intrapersonal atau sering kita pahami sebagai cara mengelola diri sehingga kita dapat menampilkan jati diri serta kepercayaan diri yang optimal, juga dikenal kecerdasan interpersonal. Kecerdasan seseorang meliputi unsure-unsur kecerdasan matematika, logika, kecerdasan bahasa, kecerdasan musical, kecerdasan visual spasial, kecerdasan kinetic, kecerdasan interpersonal, kecerdasan intrapersonal dan kecerdasan naturalis (Howard Gardner, 1993).

Kecerdasan intesrpersonal adalah salah satu kecerdasan ganda, kecerdasan interpersonal ini juga sering disebut sebagai kecerdasan social, selain kemampuan menjalain persahabatan yang akrab dengan teman yang mencakup kemampuan seperti memimpin, mesngorganisir, menangani perselisihan antar teman, memperoleh simpati dari peserta didik yang lain dan sebagainya.

Orang yang memiliki kecerdasan interpersonal yang rendah dapat memunculkan konflik interpersonal, hal ini ditegaskan oleh Sullivan bahwa penyakit mental dan perkembangan kepribadian terutama sekali lebih banyak ditentukan oleh interaksi pesrsonalnya daripada oleh factor factor konstitusionalnya. (Chaplin, 2000)

Konseling sebaya

Konseling sebaya merupakan salah satu program dalam Bimbingan Konseling. Konseling sebaya: "Peer counseling is defined as a varietsy of by non professionals who undertake a helping role with others" (Tindall 1985). Artinya konseling sebaya adalah semacam prilaku pemberian bantuan yang dilakukan oleh orang yang tidak professional, sebagai sebuah usaha membantu rekanya yang lain.

Dengan demikian konseling sebaya berarti ada proses tatap muka yaitu seorang siswa membantu siswa lain agar dapat memecahkan masalahnya sendiri. Konselor sebaya adalah menunjuk kepada orang yang membantu, untuk sementara waktu yang sebelumny6a tselah diberikan ketrampilan konseling oleh seorang ahli.

Penyeleksian calon konselor sebaya 
Untuk menjadi seorang konselor sebaya, diperlukan penyeleksian yang merupakan tugas dari pelatih (konselor) dan memegang tanggung jawab penuh bagi mereka yang terpilih. Untuk kesuksesan dalam pelaksanaan kegiatan konseling sebaya ini perlu memiliki beberapa kondisi antara lain (Tindall, 1985):

a. Peserta latihan sebaiknya individu yang memiliki kualitas kepekaan, kehangatan dan kepedulian kepada oranglain

b. Orang orang yang terlibat dalam kegiatan ini perlu memiliki kesstertarikan terhadap konsep dan aplikasi konseling sebaya.

c. Perlu adanya program latihan terencana dan spesifik, format yang dapat diberikanpun boleh dalam bentuk apapun, misalnya dalam bentuk pelajaran diklas, seminar dan lokakarya

d. Perlunya suatu pertemuan yang berdurasi sedang, psertemuan yang berduraasi pesndek tidak akan cukup untuk melatih seorang konselor sebaya yang efektif. Demikian pula halnya dengan pertemuan yang berddurasi lama juga tidak diperlukan, konselor sebaya harus distruktur dengan baik dalam yang tidak terlalu lama dan tidak pula terlalu cespat, sehingga mereka dapat mengintegrasikan latihan dengan baik.

e. Adanya evaluasi dan upaya tindaklanjut, ksegiatan ini bertujuan untuk mengukur kemajuan dan mengisolasi kemungkinan terjadinya problem, konselor sebaya yang terus menerus diberikan latihan latihan sehingga akan semakin efektif dalam memberikan bantuan kepada temanya.

Manfaat Konseling Sebaya

Konseling sebaya memiliki manfat yang dapat dibagi mesnjadi dua bagian utama, yaitu manfaat bagi Bimbingan dan Konseling disekolah dan manfaat bagi individu yang berperan aktif didalam konseling sebaya. Manfaat yang diperoleh bagi Bimbingan dan Konseling disekolah antara lain adalah membantu guru pembimbing dalam mengamati perkembangan siswa didik, dan optimalisasi layanan Bimbingan dan Konseling disekolah. Sedangkan bagi siswa adalah mampu mengeksplorasi dan mengekspresikan kemampuan dan ketrampilanya komunikasi yang lebih baik dalam pergaulan sesama sebayanya. Selain itu konseling sebaya diyakini lebih efektif dalam mengeksplorasi secara mendalam perasaan klien dan perilaku klien sehari-hari. Setidak tidaknya konseling sebaya didalam prosesnya terjadi apa yang disebut hearing (mendengarkan). Sehingga hal ini akan membuat semacam terapi psikologis secara sederhana.

Tujuan Konseling Sebaya

Beberapa tujuan konseling sebaya adalah sebagai berikut :

a. Membantu meswujutkan visi dan misi sekolah

b. Membantu konselor disekolah dalam proses pemberian layanan konseling

c. Membantu rekasnya (sesama siswa) saat menghadapi permasalan

d. Membantu konselor dalam memonitoring pesrkembangan klien (Fatonah, 2008)

Beberapa ketrampilan dasar komunikasi

Ada delapan aspek yang merupakan kestrampilan dasar dalam berkomunikasi yang perlu untuk diajarkan, yaitu ketrampilan attending, empati, meringkaskan, mengundang pertanyaan, ketulusan, konfrontasi dan problem solving (Tindall, 1985):

a. Ketrampilan attending, Atending merupakan suatu komponen yang diperlukan dalam 
komunikasi konseling.

b. Ketrampilan empati; Ketrampilan ini merupakan cara memperhatikan dan mendengarkan keluhan dari klien, konselor dapat menembus depresi (aspek perasaan) dan pengalaman yang melatar belakanginya(aspek pengalaman) serta mampu menyampaikan pemahamanya kepada klien.

c. Ketrampilan meringkaskan; merupakan suatu cara yang baik untuk mengakhiri suatu fase atrau memulai fase baru dalam wawancara konseling.

d. Ketrampilan mengundang pembicaraan; ketrampilan ini akan membantu seorang konselor untuk membuka pesrcakapan, membantu klien menunjukan pesrmasalahannya dengan tepat dan membantu mengeksplorasi aspek aspek masalahnya.

e. Ketrampilan kestulusan; ketrampilan ini adalah bagaimana konselor berbagi dengan menggunakan perasaan perasaanya secara tulus sehingga akan meningkatkan hubungan antara konselor dank lien

f. Ketrampilan berperilaku asertif; merupakan corak perilaku yang mengungkapkan pikiran, perassan, kehendak dan kepentingan secara jujur dan terus terang yang dapat diterima dan sesuai dengan sopan santun tanpa melanggar hak hak diri pribadi dan oranglain, ia tidak mau harga dirinya dilanggar, demikian pula ia tidak mau melanggar harga diri oranglain.

g. Ketrampilan mengonfrontasi; adalah membantu klien mengubah pertahanan diri yang telah diban gun guna menghindari pertibangan bidang tertentu dan untuk meningkatkan kiomunikasi yang lebih terbuka kepada konselor.

h. Ketrampilan problem solving; adalah kegiatan atau dimensi aksi yang membawa perubahan perilaku, pemecahan masalah yang efektif adalah sangat mungkin terjadi namun setelah konselor dan klien mengeksplorasi dan memahami semua dimensi persoalan, ketika hal ini telah terpenuhi maka klien berada dalam posisi membuat komitmen untuk suatu perubahan perilaku.

Pelaksanaan konseling secara umum proses konseling dibagi atas 3 tahapan, yaitu tahap awal, pertengahan dan tahap akhir.

Pada tahap awal konselor melakukan:

a. Membangun hubungan konseling yang melibatkan klien

b. Memperjelas dan mendefinisikan masalah

c. Membuat penafsiran dan penjajakan

d. Menegosiasi kontrak

Pada tahap pertengahan atau tahap kerja, konselor melakukan

a. Mengeksplorasi masalah

b. Menjaga hubungan tetap terpelihara

c. Menjaga sesuai kontrak

Pada tahap akhir, konselor mengakhiri konseling dengan persetujuan klien dan meminta klien untuk:

a. Membuat kesimpulan mengenai proses konseling

b. Mengevaluasi jalanya konseling

c. Membuat perjanjian un tuk pertemuan berikutnya sebaya (Willis, 2004).

Langkah langkah dalam konseling sebaya:

a. Salam, member perhatian dan menciptakan hubungan dan situasi nyaman 
b. Tanya, mengajukan pertanyaan untuk mengetahui klebutuhan dan perasaan klien tentang masalah yang dihadapi dan latarbelakangnya, identifikasi efek masalah terhadap klien dan hal lain.

c. Uraikan dan tawarkan informasi umum mengenai alternative pemecahan masalah untuk pengambila keputusan

d. Bantu kliesn untuk mengambil keputusan yang diinginkan beri waktu dan dorong klien untuk berpendapat

e. Jelaskan secara rinci mengenai alternative pemecahan masalah yang telah dipilih klien, konsekwensi konsekwensi yang mungkin dihadapi, ajukan psertanyaan apakah klien sudah mengerti apa yang disampaikan agar bias membuat keputusan tanpa tekanan

f. Rencanakan kunjungan ulang untuk merujuk ketempat pelayanan konseling bila diperlukan (Fatonah, 2008).

\section{Metode Penelitian}

Jenis penelitian yang digunakan adalah penelitian tindakan kelas (PTK) atau yang lebih dikenal dengan classroom action research. Empat langkah utama dalam penelitan tidakan kelas yakni: Planning, acting, observing, reflecting. Penelitian ini melibatkan 32 siswa dengan komposisi 9 laki laki dan 23 perempuan pada penelitian ini yang menjadi subyek penelitian adalah siswa yang tidak terpilih dari hasil sosiometri. Data yang diperoleh berupa data kuantitatif kemudian ditabulasi dan dianalisis secara deskriptif untuk mengetahui hasil dari PTK.

\section{Hasil dan Pembahasan}

Berdasarkan hasil angket sosiometri masih ada siswa yang terindikasi memiliki kepercayaan diri yang kurang optimal, dari 32 siswa klas XII IPA 1 terdapat 2 orang siswa yang tidak memiliki pemilih untuk kategori teman yang disukai untuk sharing/curhat. Dengan adanya data tersebut dinilai perlu untuk membantu siswa dalam menangani masalah tersebut. Hasil yang di peroleh adalah dengan penggunaan konseling sebaya dapat meningkatkan kepercayaan diri siswa disekolah pada siswa klas XII IPA 1 SMAN 9 Bandar Lampung.

Diskripsi kondisi awal, yang peneliti amati dan berdasarkan data yang diperoleh dari angket sosiometri terdapat siswa yang tidak dipilih di dalam kelasnya, dan hal tersebut menjadi focus utama dari penelitian ini, yang akan diberikan tindakan untuk terjadinya perubahan siswa menjadi lebih dapat diterima di lingkungannya dan menjadikannya lebih percaya diri.

Dari prosedur penelitian yang peneliti lakukan dapat dilaporkan sebagai berikut:

1. Planning/perencanaan

Dari hasil angket sosiometri yang disebar dan kemudian dianalisis, terdapat seorang siswa yang tidak mendapat pemilih dalam kelasnya, dari olah data tersebut(sosiogram terlampir), maka pembimbing merencanakan untuk membantu mengentaskan masalah siswa melalui strategi hubungan sebaya, untuk menentukan siswa yang akan membantu sebayanya maka dipilih siswa yang mendapat jumlah pemilih terbnanyak dikelasnya yang diindikasikan dengan hasil olah sosiometri. Sebelum konseling sebaya dilakukan, maka siswa yang akan menjadi konselor diberikan latihan ketrampilan dasar konseling sebagai dasar bagi pelaksanaan bantuan pemecahan masalah melalui konseling sebaya, dengan penilaian tentang kemampuyan siswa tersebut dalam hal ketrampilan dasar konseling. Peneliti membuat membuat satuan layanan 
sebagai pedoman dalam pelaksanaan melatih ketrampilan dasar konseling yang diketahui oleh Kepala Sekolah dan juga satuan pendukung aplikasi instrumentasi untuk angket sosiometri.

2. Action/tindakan

Pada siklus 1 pertemuan pertama yang dilaksanakan pada tanggal 10 Agustus 2012 konselor sebaya melaksanakan konseling sebaya dan melaporkan hasilnya, bahwa klien mulai memahami keterbatasanya dalam pergaulan, ketertutupannya, kurang sosialisasi dan cenderung banyak berdiam diri, kemudian konselor memberi penjelasan tentang maksud dan tujuan dilaksanakanya konseling sebaya yaitu untuk membantu membangkitkan Kepercayaan diri yang dimilikinya, maka disepakati untuk mengadakan pertemuan kedua yaitu pada tanggal 27 Agustus 2012. Hasil dari pertemuan kedua klien sudah lebih terbuka dan menceritakan persoalanya dan sudah dapat merencanakan tindakan untuk memperbaiki diri dalam hal pergaulan diklasnya untuk lebih menampilkan kepercayaan dirinya antara lain dengan upaya mencoba bergabung dengan teman temanya, membuka diri, bertegur sapa, menambah frekswensi pergaulan dan aktif diklasnya. Dan pada siklus kedua yaitu pada pertemuan tanggal 7 September 2012 dilaporkan bahwa klien dalam pergaulan sudah mengalami kemajuan, rencana rencana pribadi dalam hal kepercayaan dirinya sudah mulai ditampilkan/dipraktekan, konselor sebaya juga mencari informasi dari beberapa teman sekelasnya yang sudah melihat adanya perubahan pada klien lagi yakni menjadi lebih terbuka, sudah mulai aktif, memulai pembicaraan dan berkumpul dengan teman temanya.

\section{Observasi/pengamatan}

Dari pengamatan yang peneliti lakukan dapat di laporkan bahwa dengan konseling sebaya yang dilakukan dengan diberi latihan dasar ketrampilan konseling. Setelah dilakukan konseling sebaya sebanyak 3 kali, kemudian pembimbing memberikan angket sosiometri kedua diklas XII IPA 1 pada tanggal 6 september 2012 dan hasilnya dengan konseling sebaya siswa yang semula tidak mempunyai pemilih, kini telah mempunyai pemilih sebanyak dua orang siswa. Selanjutnya peneliti mengadakan evaluasi terhadap aspek kepercayaan diri siswa.Pada program Bimbingan dan Konseling SMAN 9 Bandarlampung, pelaksanaan layanan konseling melibatkan sebaya sebagai upaya untuk efektifitas layanan,

\section{Refleksi}

Sebelum penelitian dimulai, peneliti melakukan assessment dengan menggunakan angket sosiometri (Tgl 6 Agustus 2012, satuan pendukung dan sosiogram terlampir) dimana dari instrument ini ditemukan data sebagai berikut: siswa yang tidak terpilih atas nama HRA.1.1912 dan siswa yang mendapat pilihan terbanyak,sejumlah 7 orang atas nama Febriko Fajar, yang selanjutnya ditentukan sebagai konselor sebaya. Berdasarkan hasil assessment selanjutnya konselor melakukan penelitian pelatihan konseling sebaya pada siswa yang medapat pilihan terbanyak untuk menjadi konsaelor sebaya, yang materi, jadwal kegiatan dan satuan layananya sbb:

Tabel 1: Jadwal latihan ketrampilan konseling

\begin{tabular}{|c|c|c|c|c|}
\hline No & Tanggal & Materi pelatihan & Siswa & Keterangan \\
\hline $\mathbf{1}$ & $20-8-2012$ & $\begin{array}{l}\text { * Ketrampilan attending } \\
\text { *ketrampilan empati }\end{array}$ & Febriko & \\
\hline 2 & 27-8-2012 & *ketrampilan meringkas & Febriko & \\
\hline
\end{tabular}




\begin{tabular}{cccc}
\hline & & *ketrampilan mengundang pembicaraan & \\
& $7-9-2012$ & *ketrampilan prilaku asertif & Febriko \\
& & *ketrampilan ketulusan & \\
& *ketrampilan konfrontasi & Febriko \\
& *ketrampilan problem solving & \\
\hline
\end{tabular}

Setelah siswa yang menjadi konselor sebaya terlatih maka melakukan konseling sebaya yang pada siklus 1 dengan 2 kali pertemuan klien sudah ada perubahan yaitu mulai memahami kondisi dirinya dan tampil percaya diri dengan mulai mencoba bergabung dengan teman temanya, mebuka diri, menambah frekwensi pergaulan dan mencoba aktif, namun masih agak kaku, dan pada siklus 2 setelah dilakukan konseling sebaya klien sudah tidak canggung lagi dalam pergaulan diklasnya, memperhatikan teman, mengajak sharing dan lebih aktif, hal ini juga diperoleh informasi beberapa teman diklasnya yang dilaporkan oleh konselor sebaya kepada guru pembimbing. dan pembimbing memberikan angket tentang kepercayaan diri siswa yang hasilnya sebagai berikut:

Tabel 2 : lembar evaluasi kepercayaan diri siswa

\begin{tabular}{lc}
\hline \multicolumn{1}{c}{ Pernyataan } & Kode siswa HRA.11912 \\
\hline 1. Memulai pembicaraan & $\mathrm{v}$ \\
2. Member salam & $\mathrm{v}$ \\
3. Mendengar informasi & $\mathrm{v}$ \\
4. Memperhatikan teman & $\mathrm{v}$ \\
5. Berkumpul dengan teman & $\mathrm{v}$ \\
6. Mengajak sharing & $\mathrm{v}$ \\
7. Bertanya tentang sifat2 negatif, & $\mathrm{v}$ \\
\hline \multicolumn{1}{c}{ untuk perbaikan dirinya } & \\
\hline
\end{tabular}

Simpulan hasil refleksi pada penelitian ini dapat dirangkum sebagai berikut:

a. Klien merasa kurang terbuka

b. Klien sudah mencoba untuk memulai pembicaraan tapi masih kaku

c. Belum melaksanakan langkah langkah pemecahan masalah dalam konseling sebaya siklus 1

Setelah diberi perlakuan dengan perbaikan tindakan sesuai dengan hasil pada siklus 1 , maka hasil pada siklus dua dapat di laporkan sebagai berikut:

a. Dalam pelaksanaan konseling kelompok siklus 2 berjalan lncar, klien komunikatif dan mencari solusi atas masalahnya dengan mendengarkan pendapat dari sebayanya.

b. Konselor stidak lagi mendominasi pembicaraan

c. Kepercayaan diri siswa makin baik ditunjukan dengan penampilannya dalam pergaulan dikelas yang makin baik

d. Setelah dimonitoring selama 1 bulan siswa mengaku sudah lebih terbuka dan mau mendengar serta tidak menyendiri lagi

Pengumpulan data (data collection) dan reduksi data. Setelah dilakukan tindakan siklus 1 dan 2, dan masing masing siklus telah dilakukan observasi monitoring dan evaluasi maka hasil dari 
evaluasi konseling sebaya diperoleh data sebagai berikut:

Tabel 3: Reduksi data hasil evaluasi siswa

\begin{tabular}{|c|c|c|c|}
\hline \multirow{2}{*}{\multicolumn{2}{|c|}{$\begin{array}{c}\text { No } \\
\text { Pernyataan }\end{array}$}} & \multirow{2}{*}{$\begin{array}{l}\text { Siklus 1 } \\
\text { Y }\end{array}$} & Siklus 2 \\
\hline & & & $\mathbf{Y}$ \\
\hline 1 & $\begin{array}{l}\text { Dengan konseling sebaya saya lebih rileks } \\
\text { mengemukakan masalah }\end{array}$ & $\mathrm{v}$ & $\mathrm{v}$ \\
\hline 2 & $\begin{array}{l}\text { Melalui konseling sebaya saya merasa lebih senang dan } \\
\text { terbuka }\end{array}$ & $\mathrm{v}$ & $\mathrm{v}$ \\
\hline 3 & Saya lebih mudah diterima oleh teman teman & $\mathrm{v}$ & $\mathrm{v}$ \\
\hline 4 & Teman teman lebih menerima saya & $\mathrm{v}$ & $\mathrm{v}$ \\
\hline 5 & $\begin{array}{l}\text { Setelah konseling sebaya saya lebih mampu } \\
\text { menyampaikan pendapat }\end{array}$ & $\mathrm{v}$ & $\mathrm{v}$ \\
\hline 6 & Setelah konseling sebaya saya lebih mampu mendengar & $\mathrm{v}$ & $\mathrm{v}$ \\
\hline 7 & Mengikuti konseling sebaya dari awal sampai akhir & $\mathrm{v}$ & $\mathrm{v}$ \\
\hline 8 & $\begin{array}{c}\text { Mampu membuat rencana kegiatan unstuk } \\
\text { menyelesaikan masalah }\end{array}$ & $\mathrm{v}$ & $\mathrm{v}$ \\
\hline
\end{tabular}

Selanjutnya data hasil pengamatan kolaborator dan konselor dapat dilihat pada table berikut ini:

Tabel 4: Reduksi data hasil observasi kolaborator dan konselor

\begin{tabular}{|c|c|c|c|c|c|c|c|c|c|}
\hline \multirow[t]{3}{*}{ No } & \multirow[t]{3}{*}{ Aspek yang diobservasi } & \multicolumn{4}{|c|}{ Kolaborator } & \multicolumn{4}{|c|}{ Konselor } \\
\hline & & \multicolumn{2}{|c|}{ Siklus 1} & \multicolumn{2}{|c|}{ Siklus 2} & \multicolumn{2}{|c|}{ Siklus 1} & \multicolumn{2}{|c|}{ Siklus 2} \\
\hline & & ya & tdk & ya & tdk & ya & tdk & ya & tdk \\
\hline 1 & $\begin{array}{l}\text { Siswa aktif melaksanakan konseling } \\
\text { sebaya }\end{array}$ & $\mathrm{v}$ & & $\mathrm{v}$ & & $\mathrm{v}$ & & $\mathrm{v}$ & \\
\hline 2 & Bersedia mengungkapkan masalah & $\mathrm{v}$ & & $\mathrm{v}$ & & $\mathrm{v}$ & & $\mathrm{v}$ & \\
\hline 3 & Komunikatif & & $\mathrm{v}$ & $\mathrm{v}$ & & & $\mathrm{v}$ & $\mathrm{v}$ & \\
\hline 4 & Mampu mendengar & $\mathrm{v}$ & & $\mathrm{v}$ & & $\mathrm{v}$ & & $\mathrm{v}$ & \\
\hline 5 & Saling menghargai & $\mathrm{v}$ & & $\mathrm{v}$ & & $\mathrm{v}$ & & $\mathrm{v}$ & \\
\hline 6 & Memberi solusi & $\mathrm{v}$ & & $\mathrm{v}$ & & $\mathrm{v}$ & & $\mathrm{v}$ & \\
\hline 7 & Mengambil kesimpulan & $\mathrm{v}$ & & $\mathrm{V}$ & & $\mathrm{v}$ & & $\mathrm{v}$ & \\
\hline 8 & Membuat rencana kegiatan & $\mathrm{v}$ & & $\mathrm{V}$ & & $\mathrm{v}$ & & $\mathrm{v}$ & \\
\hline
\end{tabular}


Sedangkan hasil monitoring terhadap perubahan perilaku siswa dapat dilaporkan sebagai berikut:

Tabel 7: Reduksi data hasil monitoring kolaborator dan konselor

\begin{tabular}{|c|c|c|c|c|c|c|c|c|c|}
\hline \multirow[t]{3}{*}{ No } & \multirow[t]{3}{*}{ Aspek yang dimonitoring } & \multicolumn{4}{|c|}{ Kolaborator } & \multicolumn{4}{|c|}{ Konselor } \\
\hline & & \multicolumn{2}{|c|}{ Siklus 1} & \multicolumn{2}{|c|}{ Siklus 2} & \multicolumn{2}{|c|}{ Siklus 1} & \multicolumn{2}{|c|}{ Siklus 2} \\
\hline & & $\mathbf{Y}$ & $\mathbf{T}$ & $\mathbf{Y}$ & $\mathbf{T}$ & $\mathbf{Y}$ & $\mathbf{T}$ & $\mathbf{Y}$ & $\mathbf{T}$ \\
\hline 1 & Hubungan akrab dalam kelas & $\mathrm{v}$ & & $\mathrm{v}$ & & $\mathrm{v}$ & & $\mathrm{v}$ & \\
\hline 2 & komunikatif & $\mathrm{v}$ & & $\mathrm{v}$ & & $\mathrm{v}$ & & $\mathrm{v}$ & \\
\hline 3 & Mau mengungkapkan masalah & $\mathrm{v}$ & & $\mathrm{v}$ & & $\mathrm{v}$ & & $\mathrm{v}$ & \\
\hline 4 & Menghargai orang lain & $\mathrm{v}$ & & $\mathrm{v}$ & & $\mathrm{v}$ & & $\mathrm{v}$ & \\
\hline 5 & terbuka & $\mathrm{v}$ & & $\mathrm{v}$ & & $\mathrm{v}$ & & $\mathrm{v}$ & \\
\hline 6 & aktif & & $\mathrm{v}$ & $\mathrm{v}$ & & & $\mathrm{v}$ & $\mathrm{v}$ & \\
\hline 8 & Mengambil kesimpulan & $\mathrm{v}$ & & $\mathrm{v}$ & & $\mathrm{v}$ & & $\mathrm{v}$ & \\
\hline 9 & $\begin{array}{c}\text { Melaksanakan keputusan } \\
\text { konseling }\end{array}$ & $\mathrm{v}$ & & $\mathrm{v}$ & & $\mathrm{v}$ & & $\mathrm{v}$ & \\
\hline
\end{tabular}

Dari aspek konseling sebaya pada siklus 1 maupun siklus 2 baik data dari siswa, kolaborator maupun pemneliti menunjukan bahwa siswa memiliki perasaan yang positif ditunjukan dengan senang mengikuti kegiatan konseling sebaya dan bersungguh sungguh ingin meningkatkan kemampuan hubungan social di klasnya. Dari aspek penyesuaian diri pada siklus 1 maupun siklus 2 baik data dari siswa kolaborator maupun peneliti menunjukan bahwa siswa memiliki kemampuan penyesuaian diri/hubungan social yang lebih baik melalui konseling sebaya.

\section{Simpulan dan Saran}

Berdasarkan hasil penelitian dan pembahasan maka dapat diambil kesimpulan bahwa: Dengan berbagai latar belakang individu dan permasalahan yang beragam, konseling sebaya menjadi sebuah pilihan untuk membantu siswa dalam menyelesaikan permasalahnya, karena usia yang relative sama dan intensitas pertemuan antar siswa yang lebih banyak. Dengan demikian dapat disimpulkan bahwa penggunaan konseling sebaya dapat meningkatkan kepercayaan diri siswa pada siswa kelas XII IPA 1 SMA N 9 Bandar Lampung TP 2012 - 2013.

\section{Daftar Pustaka}

Muswardi R, Giyono dan Syarifuddin D Modul 43 Penelitian Tindakan kelas Bimbingan dan Konseling, 2008

Fatimah N, Psikologi Pserkembangan Bandung Pustaka Setia, 2006.

Yusuf S, Psikologi Pesrkembangan Anak Dan Remaja, Bdg PT Remaja Rosda Karya, 2004.

Bambang MHS, Panduan Penelitian tindakan Bimbingan dan Konseling, 2012

Fatonah, Siti dkk, Modul Pelatihan Konseling Kesehatan Reproduksi Remaja bagi calon konselor sebaya. Jakarta: Direktorat Remaja Dan Perlindungan Hak Hak Reproduksi $B K K B N, 2008$.

Gerungan W A, Psikologi social, Bandung : Refika Aditama, 2004.

Wahono, Lekad. Penggunaan Konseling Sebaya dalam meningkatkan Motivasi berprestasi 
pada siswa kelas XI SMAN 1 Bandar Lampung TP 2008/2009 (skripsi) BandarLampoung: Universitas Lampung, 2009.

Mengasah kecerdasan interpersonal siswa (interpersonal intelligence), 2010.

Thantowi, Kamus Istilah Bimbingan Dan Konseling, 2005. 